\title{
Effect of Steam Curing on Concrete Piles with Silica Fume
}

\author{
N. Yazdani, ${ }^{1)}$ F. ASCE, M. Filsaime, ${ }^{2)}$ and T. Manzur ${ }^{3)}$
}

(Received August 5, 2009, Revised April 28, 2010, Accepted May 17, 2010)

\begin{abstract}
Silica fume is a common addition to high performance concrete mix designs. The use of silica fume in concrete leads to increased water demand. For this reason, Florida Department of Transportation (FDOT) allows only a 72-hour continuous moist cure process for concrete containing silica fume. Accelerated curing has been shown to be effective in producing high-performance characteristics at early ages in silica-fume concrete. However, the heat greatly increases the moisture loss from exposed surfaces, which may cause shrinkage problems. An experimental study was undertaken to determine the feasibility of steam curing of FDOT concrete with silica fume in order to reduce precast turnaround time. Various steam curing durations were utilized with full-scale precast prestressed pile specimens. The concrete compressive strength and shrinkage were determined for various durations of steam curing. Results indicate that steam cured silica fume concrete met all FDOT requirements for the 12, 18 and 24 hours of curing periods. No shrinkage cracking was observed in any samples up to one year age. It was recommended that FDOT allow the 12 hour steam curing for concrete with silica fume.
\end{abstract}

Keywords : accelerated curing, steam curing, silica fume, shrinkage, concrete curing, pile curing

\section{Introduction}

Silica fume, also known as microsilica, has been used as a concrete property enhancing material and as a partial replacement for portland cement for over twenty-five years. Silica fume for use in concrete is available in slurry or dry forms. ${ }^{1}$ In either form, silica fume is a very reactive pozzolan when used in concrete due to its fine particles, large surface area, and the high silicon dioxide content. The concrete water demand increases with the increased amounts of silica fume, due primarily to the high surface area of the silica fume. ${ }^{2}$ Fresh concrete containing silica fume is more cohesive and less prone to segregation than concrete without silica fume (3). Since silica fume is used with other admixtures, such as water-reducing or high-range water-reducing admixtures, the slump loss is actually due to the change in chemical reactions. Silica fume is also known to affect the time of setting and bleeding of fresh concrete. Mechanical properties of silica fume concrete, such as creep and drying shrinkage, have been known to be lower than that of concrete without silica fume. ${ }^{3}$ At 28 days, the compressive strength of silica fume concrete is significantly higher than concrete without silica fume. Silica fume is also linked to the decrease of permeability, chemical attack resistance, and enhancement of the chloride ion penetration resistance of concrete. ${ }^{3}$ The surface of silica fume concrete tends to dry quickly, subsequently causing shrinkage and cracking prior to final setting. This is one reason

\footnotetext{
${ }^{1)}$ Dept. of Civil Engineering, UT Arlington, Texas 76019-0308, USA.E-mail: yazdani@uta.edu.

${ }^{2)}$ Civil Engineer, PBS\&J, Tampa, Florida33607, USA.

3)Dept. of Civil Engineering, UT Arlington, Texas 76019-0308, USA.

Copyright (c) 2010, Korea Concrete Institute. All rights reserved, including the making of copies without the written permission of the copyright proprietors.
}

why early-age moist curing of silica fume-concrete is important. ${ }^{4}$

There are several ways to cure concrete in the field. One form of curing that has become popular at precast prestressed concrete plants is accelerated curing. This type of curing is advantageous where early strength gain in concrete is important or where additional heat is required to accomplish hydration, as in cold weather. ${ }^{5}$ Accelerated curing reduces costs and curing time in the production of precast members resulting in economic benefits. ${ }^{6} \mathrm{~A}$ primary concern with accelerated curing is the potential for increased moisture loss during the curing process, as mentioned in ACI 517.2R. ${ }^{7}$ Another concern is the possible detrimental effect on long-term concrete properties from high temperatures. There is limited available information on how accelerated curing affects silica fume concrete. Some problems in strength gain have been noted in precast silica fume concrete members cured under accelerated conditions. ${ }^{8}$ These problems were resolved, however, simply by allowing the concrete to attain initial setting prior to beginning the accelerated curing process. Accelerated curing has been shown to be effective in producing high-performance characteristics at early ages in silica fume concrete. ${ }^{9}$ However, the heat from the high temperatures greatly increases the moisture loss from exposed surfaces, which tends to cause more shrinkage problems and a reduction in the ultimate strength. Prolonged curing of silica fume concrete has been recommended to ensure optimum results. The Precast/Prestressed Concrete Institute (PCI) specifically recommends over curing high-performance concrete that contains silica fume. ${ }^{9}$ There has also been a tendency to be on the safe side, since the body of knowledge on how to cure silica fume concrete most effectively and efficiently is limited. ${ }^{10}$

The Florida Department of Transportation (FDOT) Standard Specifications 346 allows the use of silica fume in concrete as 7 to $9 \%$ replacement of cementitious material, together with the usage 
of high range water reducing admixture. ${ }^{11}$ The silica fume must meet the requirements of ASTM C 1240 specifications. ${ }^{12}$ Typically, silica fume is used in FDOT higher concrete classes such as Class V and VI for increased strength and durability. These FDOT concrete classes have been tested and approved to meet specified strength, workability, durability, and several other requirements to be considered as high strength concrete classes. FDOT Specifications 450-10.8 modifications, effective January 2004, specify extended moist curing requirements for silica fume concrete. Immediately after finishing, curing blankets must be applied to all exposed surfaces and saturated with water. The moist curing must continue for a minimum of three days. Immediately afterwards, two coats of curing compound must be applied and the surfaces kept undisturbed thereafter for a minimum of seven days. This extensive curing procedure means extra expense and delays on the part of the precast yards. Although not allowed by FDOT, the process may be sped up through employing accelerated curing techniques. ASTM C-684 accelerated curing methods involving elevated temperature water use or high temperature and pressure method are not convenient for large precast prestressed elements. ${ }^{13}$ However, use of steam curing for silica fume concrete is convenient, and would mean significant economic savings and convenience for precasters. With a maximum probable steam curing time of 24 hours, the precast concrete products could be turned around at a significantly faster rate, resulting in economic benefits. It is known that steam curing results in more complete hydration of the pozzolanic materials, resulting in increased strength gain of concrete. The increased cost of the curing process is more than offset by the savings in curing time and extra productivity.

The objective of this study was to verify the feasibility of steam curing of FDOT concrete with silica fume. The study investigated the possibility of speeding up the curing process of such concrete through steam curing. The effect of such curing on several desired properties of hardened concrete were also investigated.

\section{Steam curing}

Two methods of steam curing are used: live steam at atmospheric pressure (for enclosed cast-in-place structures and large precast concrete units) and high-pressure steam in autoclaves (for small manufactured units). A steam-curing cycle, as shown in Fig. 1,

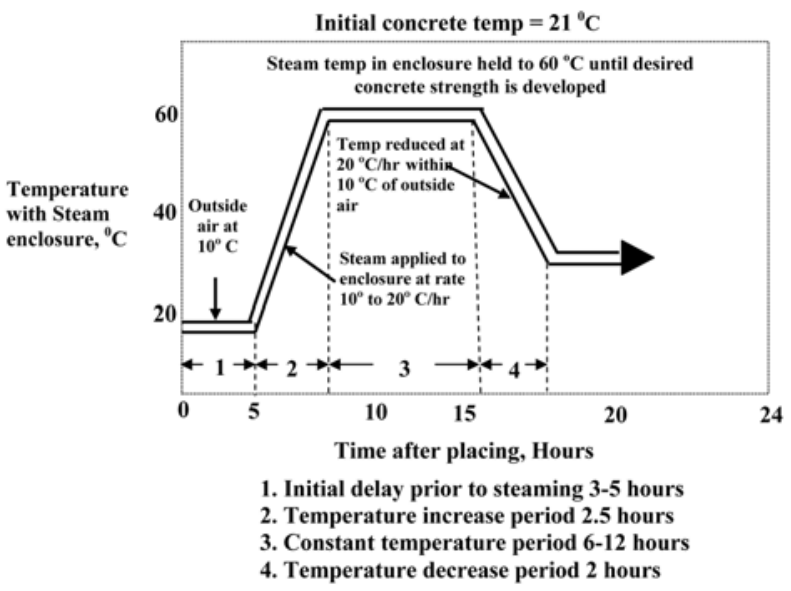

Fig. 1 A typical atmospheric steam curing cycle. (http://www.cement.ca/cement.nsf) consists of (1) an initial delay prior to steaming, (2) a period for increasing the temperature, (3) a period for holding the maximum temperature constant, and (4) a period for decreasing the temperature. ${ }^{14}$ In field practice, steam curing at atmospheric pressure is generally done in an enclosure to minimize moisture and heat loss. Part (1) of the cycle is considered to be the initial set period of the concrete. Part (2) is the time through which the temperature of the enclosure rises to the maximum temperature. During part (3) of the cycle, the concrete specimens are cured at the maximum temperature for the needed amount of time. Part (4) is the time when the temperature of the concrete is decreased to ambient conditions.

The desired maximum temperature within the enclosure and the concrete is approximately $66^{\circ} \mathrm{C}\left(150^{\circ} \mathrm{F}\right)$. It has been shown that strength will not increase significantly if the maximum steam temperature is raised from $66^{\circ} \mathrm{C}\left(150^{\circ} \mathrm{F}\right)$ to $79^{\circ} \mathrm{C}\left(175^{\circ} \mathrm{F}\right)$. Steam tem- $^{4}$. peratures above $82^{\circ} \mathrm{C}\left(180^{\circ} \mathrm{F}\right)$ should be avoided because of wasted energy and potential reduction in ultimate concrete strength. The advantage of steam curing around $66^{\circ} \mathrm{C}\left(150^{\circ} \mathrm{F}\right)$ is the potential reduction of concrete drying shrinkage and creep. Temperatures in the enclosure surrounding the concrete should not be increased or decreased more than $4^{\circ} \mathrm{C}\left(40^{\circ} \mathrm{F}\right)$ to $16^{\circ} \mathrm{C}\left(60^{\circ} \mathrm{F}\right)$ per hour.

\section{Pile sample procurement}

Full-scale precast prestressed pile specimens were monitored for shrinkage behavior under ambient conditions. The pile samples were obtained from Gulf Coast Prestress, Inc. (GCP) located at Pass Christian, Mississippi. This supplier was selected because they produce a large number of precast prestressed piles using FDOT approved mix designs. GCP maintains 22 multi-project casting beds over $121.9 \mathrm{~m}$ (400 ft.) long each, a large concrete slab area for match-casting and miscellaneous precast items, and pile spinning and assembly areas. The plant has the ability to provide steam curing to allow faster production and delivery. A total of 8 full-scale prestressed piles, cast and cured at GCP, were obtained in October 2003. They included $4-356 \mathrm{~mm} \times 356 \mathrm{~mm} \times 1.83 \mathrm{~m}$ $(14 \mathrm{in} \times 14 \mathrm{in} \times 6 \mathrm{ft})$ and $4-610 \mathrm{~mm} \times 610 \mathrm{~mm} \times 1.83 \mathrm{~m}(24 \mathrm{in}$ $\times 24$ in $\times 6 \mathrm{ft}$ ) piles. The 14 -in square piles contained $8-1 / 2$-in diameter strands, and the 24 in piles contained $16-1 / 2$ in diameter strands. Also obtained were $152.4 \mathrm{~mm} \times 304.8 \mathrm{~mm}(6$ in $\times 12$ in $)$ cylindrical specimens for compressive strength determination.

\subsection{Mix design}

The concrete ingredients used in this study were selected through consultation with the FDOT quality control personnel. The concrete mix design used was an FDOT Class V (Special) mix design with silica fume (Table 1), issued in 1995. The FDOT Class V (Special) mixes are primarily intended for use in structures requiring high performance concrete, such as piles. A Type II portland cement, conforming to AASHTO M-85 specifications was utilized in this mix design. The mix design involved two mineral admixtures, densified silica fume and Class F fly ash. The chemical admixtures used in the chosen mix were an air entrainer conforming to AASHTO M-154, Type D retarder conforming to AASHTO M-194, and Type F water reducer conforming to ASTM C 494. The coarse and fine aggregates were Grade 67 Brooksville lime rock from Brooksville, FL, and silica sand from Chattahoochee, FL, respectively. The coarse aggregate, Gradation 
Table 1 Concrete mix design.

\begin{tabular}{l|l}
\hline \multicolumn{2}{c}{ Class concrete: V Special $41 \mathrm{MPa}(6000 \mathrm{psi})$} \\
\hline \hline Parameter and properties & Value \\
\hline Cement $(\mathrm{kg})$ & 251 \\
\hline Coarse aggregate $(\mathrm{kg})$ & 798 \\
\hline Fine aggregate $(\mathrm{kg})$ & 488 \\
\hline Air entr. admix $(\mathrm{mL})$ & 166 \\
\hline $1^{\text {st }}$ admixture $(\mathrm{mL})$ & 444 \\
\hline $2^{\text {nd }}$ admixture $(\mathrm{mL})$ & 1,334 \\
\hline Water $(\mathrm{kg})$ & 87 \\
\hline Fly ash & 61 \\
\hline Slump range $(\mathrm{mm})$ & 140 to 216 \\
\hline Air content $(\%)$ & 1.0 to 5.0 \\
\hline Unit weight $(\mathrm{wet})\left(\mathrm{kg} / \mathrm{m}^{3}\right)$ & 2,275 \\
\hline W/C ratio $(\mathrm{plant})(\mathrm{kg} / \mathrm{kg})$ & 0.35 \\
\hline W/C ratio $($ field $)(\mathrm{kg} / \mathrm{kg})$ & 0.35 \\
\hline Theo yield $\left(\mathrm{m}^{3}\right)$ & 0.78 \\
\hline \multicolumn{2}{c}{ Producer test data } \\
\hline Parameter and properties & Value \\
\hline Chloride cont. $\left(\mathrm{kg} / \mathrm{m}^{3}\right)$ & 0.002 \\
\hline Slump $(\mathrm{mm})$ & 152.4 \\
\hline Air content $(\%)$ & 2.75 \\
\hline Temperature $\left({ }^{\circ} \mathrm{C}\right)$ & 38 \\
\hline Compressive strength $(\mathrm{MPa})$ & $28-\mathrm{Day}-61$ \\
\hline \multicolumn{2}{|c}{}
\end{tabular}

\#67 river gravel, had a specific gravity of 2.52. The fine aggregate, silica sand with a fineness modulus of 2.57 , had a specific gravity of 2.62. Due to the discontinuation of the silica slurry production, minor changes were made to the water added to the mix. In place of the silica slurry, $27.3 \mathrm{~kg}(60.20 \mathrm{lbs})$ of dry silica fume powder and $27.99 \mathrm{~kg}(61.70 \mathrm{lbs})$ of additional water were included in the mix design.

\subsection{Test matrix}

The test matrix (Table 2) yielded four mix combinations for each steam curing time frames and control curing; steam curing for $12,18,24$ hours and moist curing. The precast industry typically uses a curing duration of about 10 18 hours as current practice. In some cases, if the precast elements do not meet the design strength within this time span, the steam curing can be continued for as long as 24 hours. As will be discussed later, the laboratory testing included the Compressive Strength Test and Shrinkage Test. $^{15,16}$ The steam curing method nomenclature used herein contains 4 characters. The first two characters represent the steam cur-

Table 2 Test matrix.

\begin{tabular}{|c|c|c|c|}
\hline \multirow{2}{*}{ Curing* method } & \multicolumn{3}{|c|}{ Specimens } \\
\hline & Cylinders & \multicolumn{2}{|c|}{ Piles } \\
\hline \multirow{2}{*}{ Test } & $152 \mathrm{~mm} \times 305 \mathrm{mn}$ & $\overline{355 \mathrm{~mm} \times 355 \mathrm{~mm}}$ & $\overline{610 \mathrm{~mm} \times 610 \mathrm{~mm}}$ \\
\hline & $(6$ in $\times 12$ in $)$ & $(14$ in $\times 14$ in $)$ & $(24$ in $\times 24$ in $)$ \\
\hline $12 \mathrm{SM}$ & 9 & 1 & 1 \\
\hline $18 \mathrm{SM}$ & 9 & 1 & 1 \\
\hline $24 \mathrm{SM}$ & 9 & 1 & 1 \\
\hline $\mathrm{MC}$ (control) & 9 & 1 & 1 \\
\hline Total & 36 & 4 & 4 \\
\hline
\end{tabular}

*12SM: 12 hr. steam +60 hr. moist

*18SM: $18 \mathrm{hr}$. steam $+54 \mathrm{hr}$. moist

*24SM: $24 \mathrm{hr}$. steam $+48 \mathrm{hr}$. moist

*MC: 72 hr moist cure ing duration in hours. The third letter designates the fact that the specimens were steam cured, and the fourth letter represents the curing method used for the balance of the 72-hour total continuous curing requirement. ${ }^{11}$ The control non-steam moist cured specimens are designated as "MC."

\section{FDOT accelerated curing specifications}

FDOT Specification 450-10.7 contains the requirements for accelerated curing of prestressed members, and is used for nonprestressed members also. ${ }^{11}$ FDOT specifications provide separate temperature requirements for the steam curing when the ambient temperature is above or below $10^{\circ} \mathrm{C}\left(50^{\circ} \mathrm{F}\right)$. During this study, since the ambient temperature was always above $10^{\circ} \mathrm{C}\left(50^{\circ} \mathrm{F}\right)$ during the time of mixing and curing, only the specifications for the higher temperature is mentioned herein. The accelerated curing should be initiated by supply or retaining of moisture and the application of the heat, following the initial set period of the concrete. The initial set period of the concrete was determined herein using ASTM C 403 procedures. ${ }^{17}$ The FDOT specification also states that during the application of heat, the temperature rise in the concrete should not exceed $20^{\circ} \mathrm{C}\left(36^{\circ} \mathrm{F}\right)$ per hour. The maximum curing temperatures of the enclosure and concrete must not exceed $71^{\circ} \mathrm{C}\left(160^{\circ} \mathrm{F}\right)$. The maximum curing temperature has to be uniformly maintained throughout the enclosure, with variation of no more than $11^{\circ} \mathrm{C}\left(20^{\circ} \mathrm{F}\right)$ from the maximum peak temperature until the concrete reaches the required release strength. The concrete should be allowed to cool gradually at the maximum cooling rate of $27.8^{\circ} \mathrm{C}\left(50^{\circ} \mathrm{F}\right)$ per hour. The cooling rate needs to be continued until the concrete temperature is $22^{\circ} \mathrm{C}\left(40^{\circ} \mathrm{F}\right)$ or less than the ambient temperature outside the curing enclosure. If accelerated curing is completed before the minimum specified curing period of 72 hours has elapsed, curing needs to be continued for the remaining part of the curing period in accordance with one of the following curing methods: continuous moisture, membrane curing compound, or curing blankets.

\section{Concrete mixing, casting and curing}

Several factors were determined by the quality control team at GCP prior to mixing. The absorption, moisture content, and the set time of the concrete were determined to adhere to all specifications. The concrete mixing was performed using the standard concrete plant-mixing facilities at GCP. All materials used in the mix were properly controlled and monitored by a field technician. A lever arm concrete dispenser was used to cast the pile specimens, while the cylindrical specimens were manually cast. The pile specimens were vibrated using a manual vibrator during casting. The cylinders were cast according to ASTM C 192 Specifications. ${ }^{18}$ Small metal plates were partially inserted into the piles prior to hardening, in order to facilitate subsequent shrinkage determination. Three embedded sets of two metal plates were placed near the ends and at the middle of each pile. The two plates in each set were spaced approximately $254 \mathrm{~mm}$ (10 in.) apart. The external end plate was placed approximately $75 \mathrm{~mm}$ (3 in.) from the pile end, as shown in Fig. 2. After casting, the cylindrical specimens were covered with caps and the piles were covered with burlap to prevent surface moisture loss. 


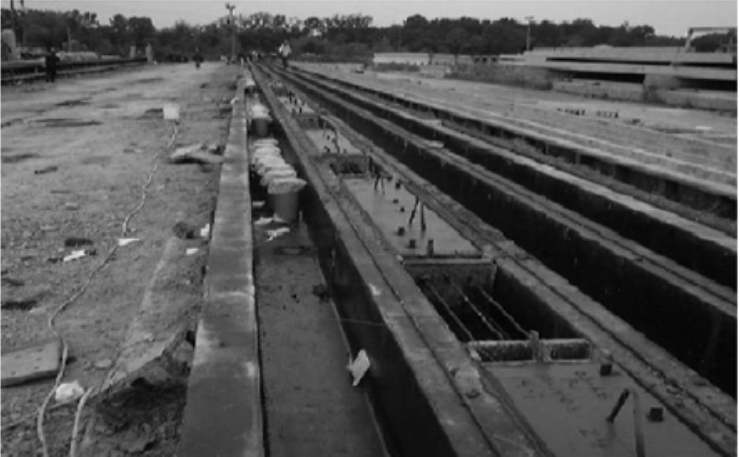

Fig. 2 Cylinders and finished piles with embedded shrinkage plates.

As stated previously, when steam curing is used, FDOT requires the temperature of the enclosure and specimens to be continuously monitored. At GCP, thermocouples were inserted into the specimens and connected to a data logger for continuous temperature monitoring (Fig. 3). Two sets of thermocouples were placed at the center of the piles before casting. After the initial set time, the 12SM, 18SM, and 24SM specimens were steam cured using low pressure steam pipes, for the proper curing times of 12,18 , or 24 hours, and then moist cured for 60, 54, and 48 hours, respectively, for the completion of the 72-hour total continuous curing period. The MC samples were moist cured for the entire 72-hour period. The piles were covered with burlap, which provided enclosure during the steam curing cycle. Because all pile specimens were cast on the same bed, the burlap was removed in sections, at the end of each steam curing period. The burlap was also used for the moist curing period, as required by FDOT. The temperatures of the specimens were monitored using the OMCP-10-TEMP thermal data logger.

\subsection{Plastic property of fresh concrete}

After mixing, a portion of the concrete was placed in a damp mixing pan and the plastic properties of the fresh concrete were determined. The tests performed were slump, temperature, and air content using the ASTM Pressure Method. ${ }^{19-21}$ Table 3 presents the determined plastics properties. The acceptable ranges for the plastic properties were as followings: slump range 140 216 mm (5.50 8.50 in) and air content 1.0 5.0\%. Table 3 shows that all 4 mixes satisfied all but slump requirement of FDOT mix design plastic property requirements. The mixes were a little bit stiff but

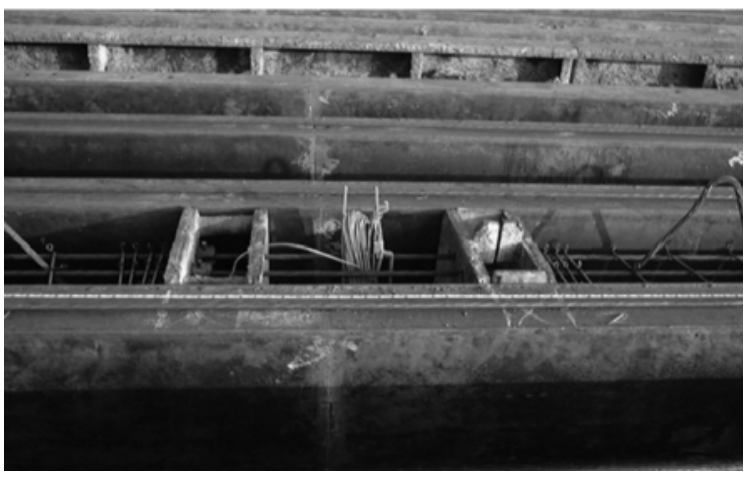

Fig. 3 Thermocouple wires for concrete piles.
Table 3 Plastic property results.

\begin{tabular}{c|c|c|c}
\hline Curing type & Slump, mm (in) & Air content $(\%)$ & Temperature, ${ }^{\circ} \mathrm{C}\left({ }^{\circ} \mathrm{F}\right)$ \\
\hline \hline 12SM & & & \\
\cline { 1 - 1 } $18 \mathrm{SM}$ & \multirow{2}{*}{$121(4.75)$} & 2.1 & $30(86)$ \\
\cline { 1 - 1 } MC (control) & & & \\
\hline
\end{tabular}

*12SM: 12 hrs. steam + 60 hrs. moist

*18SM: 18 hrs. steam + 54 hrs. moist

*24SM: 24 hrs. steam +48 hrs. moist

*MC: 72 hrs moist cure

this did not affect the concrete placement, since the air content was within the limit.

\subsection{Steam curing temperatures}

At the precast yard, major emphasis was placed on the continuous temperature reading of the specimens during curing, and less on the temperature in the specimens during the cooling period. Therefore, the temperature readings described in this section reflect the average temperature during the steam curing. Fig. 4 displays the temperature of the concrete specimens during periods 2 and 3 of the steam curing cycle, as described in Fig. 1. Channels 1 and 2 correspond to the temperature in the $610 \mathrm{~mm}$ (24 in) specimens, and Channels 3 and 4 correspond to the $356 \mathrm{~mm}$ (14 in) specimens. Approximately a $10^{\circ} \mathrm{C}\left(50^{\circ} \mathrm{F}\right)$ temperature difference existed in the maximum curing temperatures for the two pile groups. This may be due to the size effect and specimen location during curing. The larger piles are expected to build up more heat at their cores. The larger pile casting bed was located nearest to the boiler used to heat the water, while the smaller piles were located further away. However, it is obvious that the GCP pile specimen steam curing temperature cycles satisfied the FDOT requirements.

\subsection{Transportation and storage}

The time span between the initial construction of the piles and the delivery of the piles spanned 14 days. The specimens were delivered to the FAMU/FSU College of Engineering in Tallahassee, FL, by means of a flat bed truck. Upon delivery the specimens were placed on a combination of concrete blocks and $2 \times 4$ lumbers. They were exposed to ambient conditions for the 364-day duration of the study.

\subsection{Compressive strength test}

The compressive strength test was performed in accordance

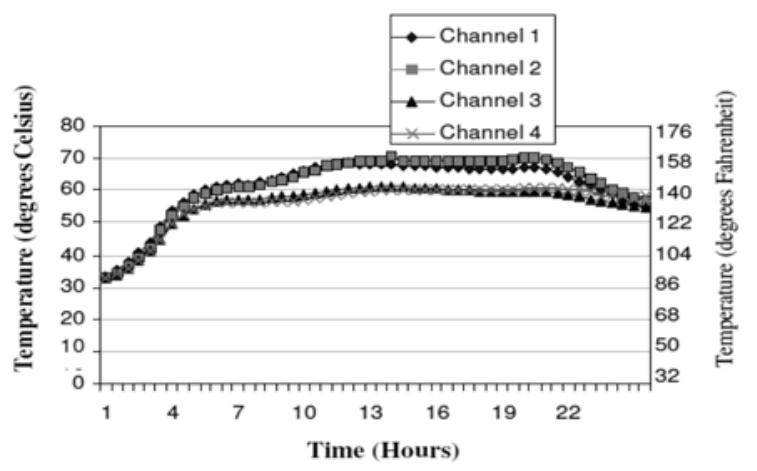

Fig. 4 Steam curing temperatures. 
with ASTM C 39..$^{15}$ The compressive strength results are presented in Fig. 5. All samples reached the target compressive strength of $41 \mathrm{MPa}(6,000 \mathrm{psi})$ at 28 days, and they continued to gain strength beyond 28 days. The 12SM specimens were the highest strength producers among the steam cured specimens at 365 days, followed by the 18SM samples, as shown in Fig. 5. The moist cured MC specimens displayed high compressive strengths at 28 days and consistently at all other ages. The MC specimens were kept submerged under water for constant curing that eventually resulted in higher strength. At 91-day, the 12SM samples displayed the second highest compressive strengths, followed by the 24SM specimens. The 18SM specimens displayed the least compressive strength. Stem curing are often more feasible than the moist curing as they require less time and for ease of application. Though stem curing methods resulted in comparatively less strength than the MC specimens, all of them satisfied the minimum required strength by FDOT.

\subsection{Shrinkage test}

Because the ASTM C 490 shrinkage specification is designed for small-scale samples, the procedure was slightly modified to make it applicable to large pile samples. As mentioned previously, metal plates were inserted into the pile surfaces prior to concrete hardening. The outside distances between the pairs of embedded steel plates were measured weekly with a micrometer (Figs. 6 and 7). A total of 3 readings were taken from each pair of shrinkage plates, and the average of the three readings was recorded as the gage length $\left(L_{x}\right)$. It was also not possible to immerse the large pile samples continuously in lime solutions, as specified by ASTM C $490 .^{22}$ Because the piles were exposed to ambient conditions, the relative humidity and temperature changes over time were expected to affect the drying shrinkage. A correction factor is

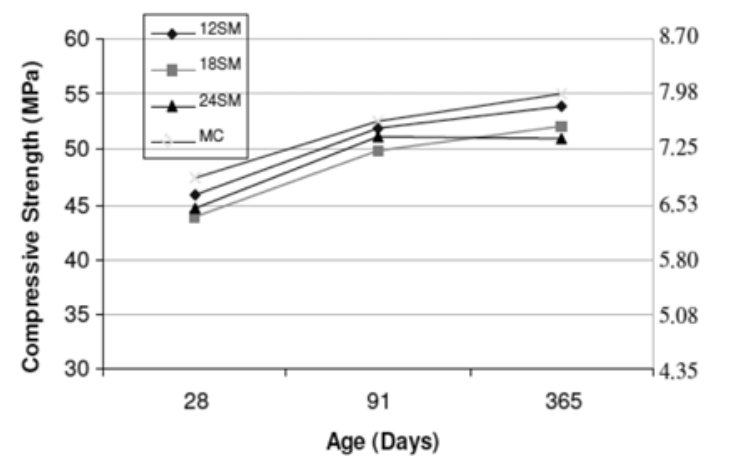

Fig. 5 Compressive strength results.

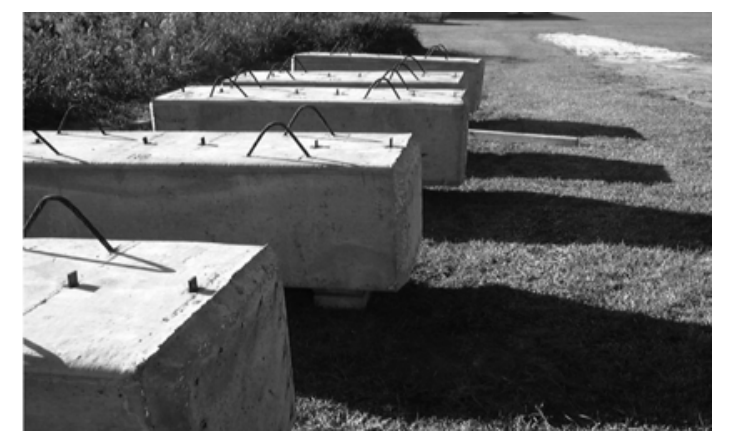

Fig. 6 Piles with embedded metal plates.

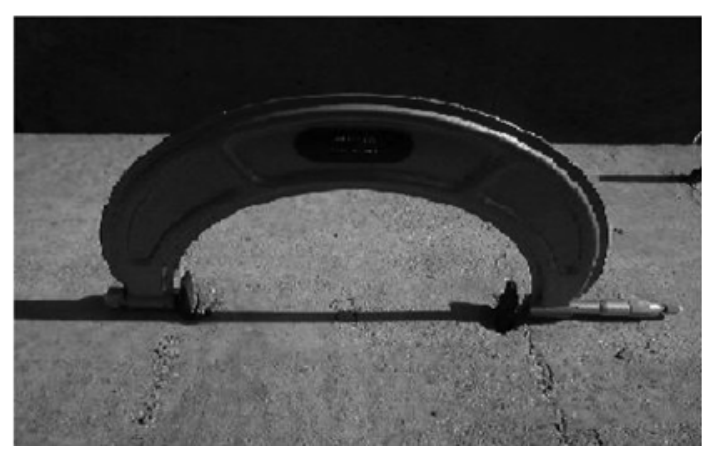

Fig. 7 Micrometer measurement of embedded plate distance.

applied to the actual shrinkage of the concrete when the ambient humidity is greater than $40 \%$, and the net shrinkage after humidity corrections was obtained as follows:

$$
\left(\varepsilon_{\mathrm{sh}}\right)_{\text {net }}=\left(\varepsilon_{\mathrm{sh}}\right)_{\mathrm{t}} \times(\mathrm{CF})_{\mathrm{H}}
$$

For conditions other than the standard $40 \%$ ambient humidity, a correction factor $(\mathrm{CF})$ is applied as follows:

$$
\begin{aligned}
& (\mathrm{CF})_{\mathrm{H}}=1.40-0.010 \mathrm{H}, 40 \leq \mathrm{H} \leq 80 \% \\
& (\mathrm{CF})_{\mathrm{H}}=3.00-0.030 \mathrm{H}, \mathrm{H} \geq 80 \%
\end{aligned}
$$

where $\mathrm{H}$ is the relative humidity in percent.

Equation 4 was then used to calculate the shrinkage occurring on the pile surface, as follows:

$$
L=\frac{L_{x}-L_{i}}{L_{i}}
$$

where

$L=$ shrinkage at age $\mathrm{x}$

$L_{x}=$ micrometer reading at age $\mathrm{x}$

$L_{i}=$ initial micrometer reading at the time of removal from mold

The micrometer was graduated to read in $0.00254 \mathrm{~mm}(0.0001$ in) units, matching the minimum accuracy of $0.00254 \mathrm{~mm}$ (0.0001 in) units specified in ASTM C 490.

Sample graphical representations of the modified shrinkage and best-fit regression trendlines for the small and large pile specimens are shown in Figs. 8 and 9, respectively. The least amount of shrinkage occurred in the moist cured specimens for both the small and large pile specimens at 350 days. Among the steam cured specimens, the least shrinkage occurred within the 18SM specimens followed by the 12SM specimens for the small piles. The greatest amount shrinkage occurred within the 24SM samples. For the larger piles, the moist cured samples again performed best for shrinkage at 350 days, followed in order by the $24 \mathrm{SM}$, 12SM, and 18SM samples, respectively.

\subsection{Size effect on shrinkage}

The shrinkage growth for the small and large 12SM specimens were similar, with the larger shrinkage occurring within the smaller specimens. The small and large 18SM pile specimens 


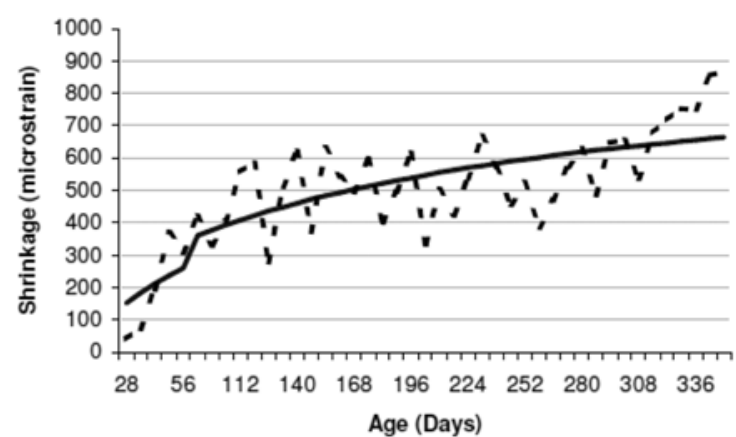

(a) $12 \mathrm{SM}$ specimens

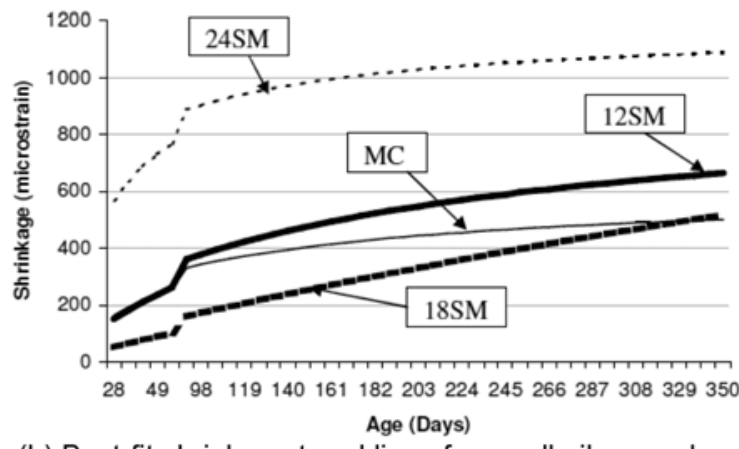

(b) Best-fit shrinkage trend lines for small pile samples

Fig. 8 Shrinkage results for small piles.

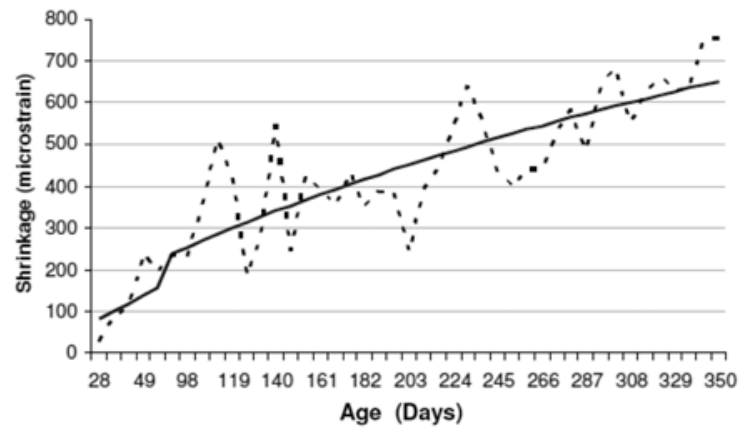

(a) $12 \mathrm{SM}$ specimens

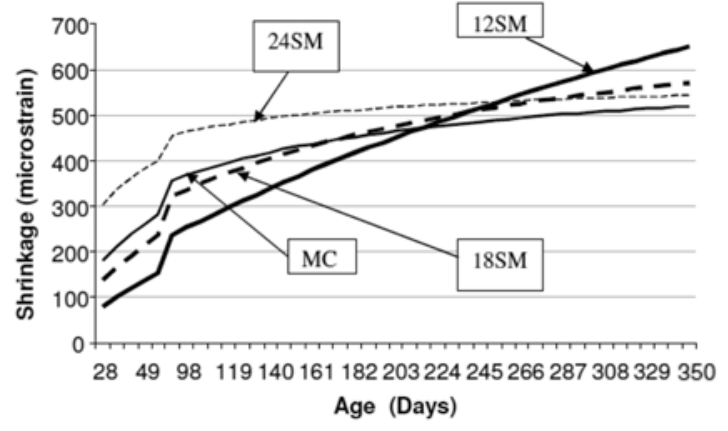

(b) Best-fit shrinkage trend lines

Fig. 9 Shrinkage results for large piles.

show more difference in shrinkage growth, with the greater amount of shrinkage occurring within the larger specimens. The specimens that were moist cured demonstrated a very small difference in shrinkage between the two different sized samples. The small and large 24SM pile specimens displayed a large difference in shrinkage rates, with the larger shrinkage occurring.

\section{$5.7 \mathrm{ACl}$ shrinkage prediction}

Due to the many variables among mix designs and several external factors that affect shrinkage within concrete, there is no current minimum or maximum amount of shrinkage that are allowable for design. ACI adopted the Branson expression for shrinkage strain, Eqs. (5) and (6). The hyperbolic expression is based on several studies conducted under controlled environment. The ultimate shrinkage, $\left(\varepsilon_{\mathrm{sh}}\right)_{\mathrm{u}}$, with a value of $800 \times 10^{-6} \mathrm{~mm} / \mathrm{mm}$ (in/in) at $40 \%$ humidity, is based on the Branson ultimate shrinkage strain at five years. ${ }^{23}$

For any time $t$ after age 7 days for moist-cured concrete,

$$
\left(\varepsilon_{s h}\right)_{t}=(t /(35+t))\left(\varepsilon_{s h}\right)_{u}
$$

For anytime after 1 to 3 days for steam-cured concrete,

$$
\left(\varepsilon_{s h}\right)_{t}=(t /(55+t))\left(\varepsilon_{s h}\right)_{u}
$$

where

$\left(\varepsilon_{s h}\right)_{t}=$ shrinkage strain at anytime $t$ after the recommended ages

$t \quad=$ time in days after initial curing

$\left(\varepsilon_{s h}\right)_{u}=$ ultimate shrinkage strains; average value suggested is

$800 \times 10^{-6} \mathrm{~mm} / \mathrm{mm}$ (in/in) at $40 \%$ humidity.

A comparison of the shrinkage growth curve from this study and the ACI shrinkage curve was conducted herein. ACI Eqs. (2) and (3) were calculated at various concrete ages. ACI supplies only one generic shrinkage curve for all steam curing durations. The ACI shrinkage model at 365 -day age predicts a shrinkage of about $534 \times 10^{-6}$ and $565 \times 10^{-6}$ for steam curing and moist curing, respectively, as expected. Most of the $356 \mathrm{~mm}$ (14 in) pile specimens displayed a shrinkage strain between $500 \sim 1,000 \times 10^{-6}$, well above the ACI prediction. The $356 \mathrm{~mm}$ (14 in) moist cured specimens showed a strain of about $500 \times 10^{-6}$ at 365 days, slightly less than the ACI prediction. For the $610 \mathrm{~mm}$ (24 in) piles, the 365-day shrinkage was $550 \sim 650 \times 10^{-6}$, close to the ACI prediction. The moist cured $610 \mathrm{~mm}(24 \mathrm{in})$ pile samples showed 365-day shrinkage that were very close to the ACI prediction.

\section{Conclusions}

The following conclusions may be made based on the findings of this study:

1) Steam curing of silica fume precast concrete elements can be conveniently achieved with the present day technology and facilities available in large precast yards. This study has shown that it is easily possible to meet and even exceed the FDOT specifications regarding the temperature regimens during steam curing.

2) Steam cured silica fume concrete can achieve the target minimum compressive strengths, as specified in the FDOT specifications. In this study, all steam cured pile specimens reached the 28day target strength of $41.37 \mathrm{MPa}(6,000 \mathrm{psi})$ for the Class V mixes. All steam cured samples continued to gain in strength with time. At 365 day age, the samples displayed significantly higher compressive strengths than the 28-day strengths.

3) Steam curing times of 12,18 and 24 hours do not seem to play a major role in controlling concrete compressive strengths. There was no consistent pattern of maximum strength displayed 
by samples from a single source of steam cured duration.

4) All steam cured and moist cured specimens showed a general increase in shrinkage with time. The steam curing duration did not seem to play a major role in affecting the shrinkage rates. At later stages, such as 364 days age, the longer steam curing periods such as 18 and 24 hours accelerated the shrinkage growth.

5) During the 364 days of monitoring, no distress of the prestressed piles was observed due to shrinkage cracking. Visual inspections did not show any shrinkage cracks.

6) The ACI Branson model for shrinkage prediction under-predicts the shrinkage of steam cured specimens at 364 days, and over-predicts for the moist cured specimens.

7) Precast yards may adopt a 12 24 hours period of steam curing for silica fume concrete elements. Typical current steam curing duration used by precasters is $10 \sim 18$ hours.

It is recommended that FDOT continue the practice of 72 hours continuous total curing of silica fume concrete products. This means that the balance of the 72 hours requirement after the end of the steam curing time will be used for moist curing. The moist curing may be achieved through curing blankets or curing compound application.

\section{Acknowledgements}

The study reported herein was performed under a research grant from FDOT. The technical assistance received from Mr. Ghulam Mujtaba, Mr. Mike Bergin and Mr. Charles Ishee of the FDOT Materials Laboratory in Gainesville, FL, is gratefully acknowledged.

\section{Notations}

The following symbols are used in this paper

$\left(\varepsilon_{\mathrm{sh}}\right)_{\mathrm{t}}=$ shrinkage strain at anytime $\mathrm{t}$ after the recommended ages

$\left(\varepsilon_{\mathrm{sh}}\right)_{\mathrm{u}}=$ ultimate shrinkage strains; average value suggested is $800 \times 10^{-6} \mathrm{~mm} / \mathrm{mm}$ (in/in) at $40 \%$ humidity.

$\mathrm{L}=$ shrinkage at age $\mathrm{x}$

$\mathrm{L}_{\mathrm{x}} \quad=$ micrometer reading of specimen at age $\mathrm{x}$

$\mathrm{L}_{\mathrm{i}} \quad=$ initial micrometer reading of specimen at the time of removal from mold

$\mathrm{t} \quad=$ time in days after initial curing

\section{References}

1. ACI Committee 234 Report, Guide for the Use of Silica Fume in Concrete, ACI Manual of Concrete Practice: Materials and General Properties of Concrete (Part 1): 234R1 - 234R51 American Concrete Institute, Farmington Hills, MI, 1997.

2. Scali, M. J., Chin, D., and Berke, N. S., "Effect of Microsilica and Fly Ash upon the Microstructure and Permeability of Concrete," Proceedings, $9^{\text {th }}$ International Conference on Cement Microscopy, Duncanville, TX: International Cement Microscopy Association, 1987, pp. 375 387.

3. ACI Committee 363 Report, High Strength Concrete, ACI Manual of Concrete Practice: Materials and General Properties of Concrete (Part 1): 363R1 - 363R55, American Concrete Institute, Farmington Hills, MI, 1997.

4 Ozyildirim, C., "Concrete Bridge-Deck Overlays Containing Silica Fume," CANMET/ACI International Workshop on the
Use of Silica Fume in Concrete, April 7- 9, 1991, Washington, DC, V.M. Malhotra, Ed., pp. 305 312.

5. Cement Association of Canada, Autoclave Steam Curing and Atmospheric Steam Curing, Cement Association of Canada. 2004.

6. Thelend, D., "The Make-or-Break Process: With and Eye on the Bottom Line, the Producer Increasingly is Trying to Optimize the Curing Process," The Concrete Producer, July 2003.

7. ACI Committee 517.2 Report, "Accelerated Curing of Concrete at Atmospheric Pressure - State of the Art," ACI Manual of Concrete Practice, American Concrete Institute, Farmington Hills, MI, 1992.

8. Holland, T. C., "Working with Silica Fume in Ready-Mixed Concrete," U.S.A Experience Proceedings, 3 rd International Conference, Fly Ash, Silica Fume, Slag, and Natural Pozzolans in Concrete, SP-114, Farmington Hills, MI, Vol. 2, 1989, pp. 763 781.

9. PCI Committee on Durability, "Guide to Using Silica Fume in Precast/Prestressed Concrete Products," PCI Journal, Vol. 39, 1994, pp. 36 46.

10. Ayers, M. E. and Khan, M. S., "Overview of Fly Ash and Silica Fume Concrete: The Need for Rational Curing Standards," Proceedings of V. Mohan Malhotra Symposium, Concrete Technology: Past, Present, and Future, SP-144, 1994, Farmington Hills, MI, pp. 605 622.

11. Florida Department of Transportation, Standard Specifications for Road and Bridge Construction, Tallahassee, Florida, 2004.

12. ASTM Designation: C 1240, Standard Specification for Silica Fume for Use as a Mineral Admixture in Hydraulic Cement Concrete, Mortar, and Grout, Philadelphia, PA, 2003.

13. ASTM Designation: C 684, Standard Test Method for Making, Accelerated Curing, and Testing Concrete Compression Test Specimens, Philadelphia, PA, 1999.

14. Kosmatka, S. H. and Panarese, W. C., Design and Control of Concrete Mixtures, $13^{\text {th }}$ e.d. Portland Cement Association, 1994.

15. ASTM Designation: C 39, Standard Test Method for Compressive Strength of Cylindrical Concrete Specimens, Philadelphia, PA, 2003.

16. ASTM Designation: C 157, Standard Test Method for Length Change of Hardened Hydraulic Cement Mortar and Concrete, Philadelphia, PA, 2003.

17. ASTM Designation: C 403, Standard Test Method for Time of Setting of Concrete Mixtures by Penetration Resistance, Philadelphia, PA, 1999.

18. ASTM Designation: C 192, Standard Practice for Making and Curing Concrete Test Specimens in the Laboratory, Philadelphia, PA, 2001.

19. ASTM Designation: C 143, Standard Test Method for Slump of Portland Cement Concrete, Philadelphia, PA, 2003.

20. ASTM Designation: C 1064, Standard Test Method for Temperature of Freshly Mixed Portland Cement Concrete, Philadelphia, PA, 1999.

21. ASTM Designation: C 173, Standard Test Method for Air Content of Freshly Mixed Concrete by the Volumetric Method, Philadelphia, PA, 2003.

22. ASTM Designation: C 490, Standard Practice for Use of Apparatus for the Determination of Length Change of Hardened Cement Paste, Mortar, and Concrete, Philadelphia, PA, 2000.

23. Branson, D. E., Deformation of Concrete Structures, McGrawHill International Book Co., 1977. 